\title{
Influence of Consciousness Energy Healing Treatment on the Properties of Polylactic-co- Glycolic Acid (PLGA)
}

ISSN: 2576-9170

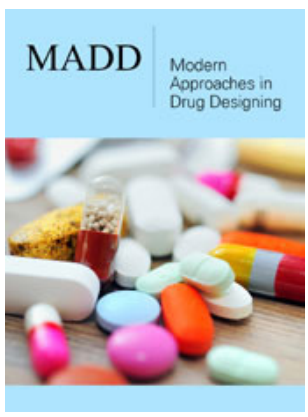

*Corresponding author: Snehasis Jana, Trivedi Science Research Laboratory Pvt Ltd, Thane (W), Maharashtra, India

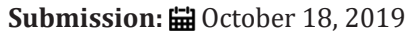

Published: 眥 November 04, 2019

Volume 2 - Issue 4

How to cite this article: Dahryn $\mathrm{T}$, Mahendra KT, Alice B, Gopal N, Snehasis J. Influence of Consciousness Energy Healing Treatment on the Properties of Polylacticco-Glycolic Acid (PLGA). Mod Appro Drug Des.2(4). MADD.000544.2019. DOI: 10.31031/MADD.2019.02.000544.

Copyright@ Dahryn Trivedi, This article is distributed under the terms of the Creative Commons Attribution 4.0 International License, which permits unrestricted use and redistribution provided that the original author and source are credited.

\author{
Dahryn Trivedi ${ }^{1}$, Mahendra Kumar Trivedii $^{1}$, Alice Branton ${ }^{1}$, Gopal Nayak ${ }^{1}$ and \\ Snehasis Jana ${ }^{2 *}$ \\ ${ }^{1}$ Trivedi Global Inc, USA \\ ${ }^{2}$ Trivedi Science Research Laboratory Pvt Ltd, India
}

\begin{abstract}
Polylactic-co-glycolic acid (PLGA) is the most popular biodegradable copolymers have several applications in the pharmaceuticals and biomedical industries, but degradation and stability of PLGA are major apprehensions. The aim of this study was to evaluate the impact of the Trivedi Effect ${ }^{\circledR}$ on the physicochemical and thermal properties of PLGA using a number of analytical techniques. The PLGA powder sample was divided into two parts, one part of the test samples was considered as a control sample, whereas the other part of PLGA samples received the Trivedi Effect ${ }^{\circledR}$-Consciousness Energy Healing Treatment remotely by a well-known Biofield Energy Healer, Dahryn Trivedi and termed as a Biofield Energy Treated sample. The particle size values of the treated PLGA powder were significantly decreased by $48.08 \%\left(\mathrm{~d}_{10}\right), 40.08 \%\left(\mathrm{~d}_{50}\right), 33.78 \%\left(\mathrm{~d}_{90}\right)$, and $37.17 \%\{\mathrm{D}(4,3)\}$ compared to the control sample. Hence, the specific surface area of the treated PLGA powder sample was significantly increased by $72.57 \%$ compared to the control sample. The PXRD diffractograms of the control and treated PLGA powder sample did not show sharp and intense peaks, indicated that both the samples were amorphous. The evaporation and melting temperature of the treated sample were slightly altered by $1.31 \%$ and $-0.94 \%$, respectively compared with the control sample. But, the latent heat of evaporation and latent heat of fusion of the treated PLGA sample were significantly increased by $6.91 \%$ and $116.91 \%$, respectively compared with the control sample. The total weight loss was significantly decreased by $4.1 \%$; however, the residue amount was $21.99 \%$ more in the treated PLGA sample compared to the control sample. The maximum thermal degradation temperature of the treated PLGA was altered by $2.37 \%$ compared with the control sample. From the results, it was established that the Trivedi Effect ${ }^{\circledR}$-Consciousness Energy Healing Treatment might introduce a new form of PLGA, which would show better solubility, dissolution rate, absorption, bioavailability, and thermal stability compared with the control PLGA. This the Trivedi Effect ${ }^{\circledR}$-Consciousness Energy Healing Treated PLGA would be a better choice for the pharmaceutical formulations, i.e., the drug like amoxicillin, simvastatin, minocycline, and vancomycin loaded PLGA nanoparticles and manufacturing of biomedical devices, i.e., grafts, surgical sealant films, sutures, prosthetic devices, implants, micro, and nanoparticles.
\end{abstract}

Keywords: The Trivedi Effect ${ }^{\circledR}$; Consciousness energy healing treatment; Polylactic-co-glycolic acid; Particle size; Surface area; DSC; TGA/DTG

\section{Introduction}

Polylactic-co-glycolic acid (PLGA) is most popular among the several available biodegradable polymers with long clinical experience [1]. It is a synthetic copolymer of polylactic acid and glycolic acid (Figure 1). On hydrolysis in the presence of water release the monomers. The monomers, i.e., polylactic acid and glycolic acid are the by-products of various metabolic pathways in the body, hence exhibit minimum systemic toxicity. The higher the content of glycolide units in the PLGA lower the time for degradation. PLGA gained importance in the research and development due to its mechanical resistance, constant biodegradation rate, and regular individual chain geometry [2]. It is very much important for the manufacturing of biomedical devices, i.e., grafts, sutures, surgical sealant films, prosthetic devices, implants, micro, and nanoparticles [3]. It is among the FDA-approved polymers that have been extensively studied as delivery vehicles for drugs, proteins, and other macromolecules such as peptides, RNA, and DNA [1]. Specifically, PLGA is useful for the 
designing of better pharmaceuticals formulations, i.e., the drug like simvastatin, vancomycin, amoxicillin, and minocycline loaded PLGA nanoparticles could be effective in sustain drug release [4-6]. PLGA contains less than $50 \%$ glycolic acid units is easily soluble in most common organic solvents. But, PLGA rich in glycolyl units more than $50 \%$ is insoluble in most organic solvents [7,8]. Anhydride form of PLGA has adequate heat stability [9]. The stability is a major concern for PLGA, which completely depends upon the monomer percentage, chain-ends chemical composition, porosity, size, shape, and presence of additives, moisture, and temperature [10-12].

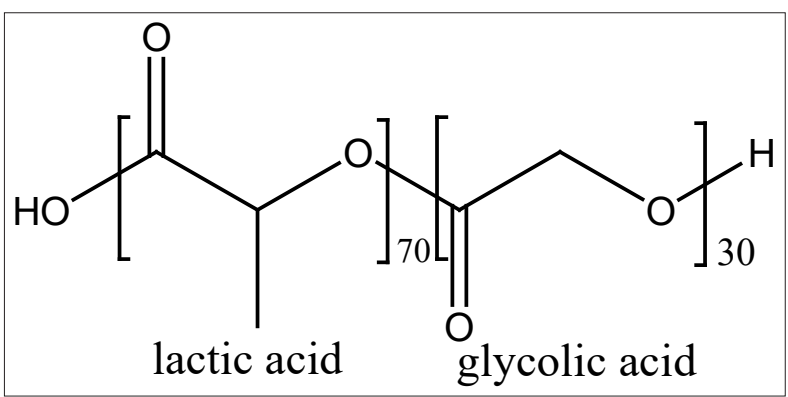

Figure 1: Polylactic-co-glycolic acid (PLGA, 70:30).

The Trivedi Effect ${ }^{\circledR}$-Consciousness Energy Healing treatment has been scientifically studied and claimed to have a significant influence on altering the crystallite size, particle size, surface area, solubility, melting point, latent heat, etc. of the object(s) [13-15]. The Trivedi Effect ${ }^{\circledR}$ is a natural and scientifically proven phenomenon in which a skilled person can harness this inherently intelligent energy from the "Universe" and transfer it anywhere on the planet via the possible mediation of neutrinos [16]. Due to the continuous movement of the charged particles, i.e., ions, cells, etc. inside the body, a unique para-dimensional electromagnetic field generated inside the body is called "Biofield" (A putative energy field). Biofield Energy Healers can harness the energy from the Universe and can transmit into any living or non-living object(s) around the earth. Biofield Energy Healing therapy has been recognized as a Complementary and Alternative Medicine (CAM) health care approach by the National Center of Complementary and Integrative Health (NCCIH) with other therapies and accepted by most of the world population $[17,18]$. The Biofield Energy Healing Therapies have been accepted worldwide and reported in many scientific journals with significant outcomes against various diseases and improved quality of life [19,20]. Similarly, the Trivedi Effect ${ }^{\circledR}$-Consciousness Energy Healing Treatment also reported with the significant outcomes in different field of sciences, i.e., organic chemistry [21], material science [22], nutraceutical/ pharmaceutical sciences $[23,24]$, microbiology $[25,26]$, agriculture [27], biotechnology [28], and medical science [29]. All these study results encouraged to evaluate the influence of the Trivedi Effect ${ }^{\circledR}$ Consciousness Energy Healing Treatment on most popular polymer PLGA using particle size analysis (PSA), powder X-ray diffraction (PXRD), differential scanning calorimetry (DSC) analytical techniques, and thermogravimetric analysis (TGA)/ Differential thermogravimetric analysis (DTG).

\section{Materials and Methods}

\section{Chemicals and reagents}

The test sample polylactic-co-glycolic acid (PLGA, 70:30; CAS registry number 30846-39-0) powder was purchased from Changchun Hang Gai Biological Technology Co., Ltd., China. The sunflower oil used for particle size analysis was of analytical grade purchased in India.

\section{Consciousness energy healing treatment strategies}

PLGA powder sample was considered as the test sample, which divided into two parts. One part of the test samples was received the Trivedi Effect ${ }^{\circledR}$-Consciousness Energy Healing Treatment remotely under standard laboratory conditions for 3 minutes by the renowned Biofield Energy Healer, Dahryn Trivedi (USA), known as the Biofield Energy Treated sample. The other part of the test sample was considered as a control sample, which was not received with Biofield Energy Treatment. But the control sample was treated with a "sham" healer who did not have any knowledge about the Biofield Energy Treatment. After all the treatment, the treated and untreated PLGA powder samples were kept in the sealed conditions and characterized using sophisticated analytical techniques.

\section{Characterization}

The PSA was performed with the help of Malvern Mastersizer 2000, from the UK using the wet method [30,31]. The PXRD analysis of PLGA powder sample was performed with the help of Rigaku MiniFlex-II Desktop X-ray diffractometer (Japan) [32,33]. The average size of crystallites was calculated using the Scherrer's formula (1)

$$
G=k \lambda / \beta \cos \theta
$$

Where $\mathrm{G}=$ crystallite size $(\mathrm{nm}), \mathrm{k}=$ equipment constant (0.94), $\lambda=$ radiation wavelength $(0.154056 \mathrm{~nm}$ for $\mathrm{K} \alpha 1$ emission $), \beta=$ full width at half maximum, and $\theta=$ Bragg angle [34].

Similarly, the DSC of PLGA was performed with the help of DSC Q200, TA instruments. The TGA/DTG of PLGA was performed with the help of TGA Q50 TA instruments [30,31].

The \% change in the Biofield Energy Treated sample was calculated compared with the control sample using the following equation 2 :

$$
\% \text { Change }=\frac{[\text { Treated }- \text { Control }]}{\text { Control }} \times 100(2)
$$

\section{Results and Discussion}

\section{Particle Size Analysis (PSA)}

The particle size distribution analysis of both the control and Biofield Energy Treated PLGA powder sample were performed, and the results are presented in Table 1 . The particle size values in the Biofield Energy Treated PLGA powder sample was significantly decreased by $48.08 \%, 40.08 \%, 33.78 \%$, and $37.17 \%$ at $\mathrm{d}_{10}, \mathrm{~d}_{50}, \mathrm{~d}_{90}$, and D $(4,3)$, respectively compared to the control sample (Table 1). The specific surface area (SSA) of the Biofield Energy Treated 
PLGA powder sample $\left(0.0302 \mathrm{~m}^{2} / \mathrm{g}\right)$ was significantly increased by $72.57 \%$ compared with the control sample $\left(0.0175 \mathrm{~m}^{2} / \mathrm{g}\right)$. The Trivedi Effect ${ }^{\circledR}$-Consciousness Energy Healing Treatment might have fractured the larger particles into smaller ones, hence increased the surface area of the PLGA particle. The particle size of a compound has a significant effect on the solubility, dissolution, absorption, and bioavailability of it $[35,36]$. Thus, the Biofield Energy Treated PLGA would show more solubility, dissolution, absorption, and bioavailability compared to the control sample. This treated PLGA would be better for the pharmaceutical formulations and biomedical devices manufacturing industry using it as a raw material.

Table 1: The particle size distribution of the control and treated PLGA.

\begin{tabular}{|c|c|c|c|c|c|}
\hline Parameter & $\mathbf{d}_{\mathbf{1 0}}(\boldsymbol{\mu m})$ & $\mathbf{d}_{\mathbf{5 0}}(\boldsymbol{\mu m})$ & $\mathbf{d}_{\mathbf{9 0}}(\boldsymbol{\mu m})$ & $\mathbf{D}(\mathbf{4 , 3})(\boldsymbol{\mu m})$ & $\mathbf{S S A}\left(\mathbf{m}^{\mathbf{2}} \mathbf{g}\right)$ \\
\hline Control & 200.935 & 577.416 & 1227.608 & 653.678 & 0.0175 \\
\hline Biofield Treated & 104.316 & 346.014 & 812.953 & 410.693 & 0.0302 \\
\hline Percent change* $(\%)$ & -48.08 & -40.08 & -33.78 & -37.17 & 72.57 \\
\hline
\end{tabular}

$\mathrm{d} 10, \mathrm{~d} 50$, and $\mathrm{d} 90$ are particle diameter corresponding to $10 \%, 50 \%$, and $90 \%$, respectively of the cumulative distribution. $\mathrm{D}(4,3)$ is the average mass-volume diameter. SSA is the specific surface area. *denotes the percentage change in the particle size distribution of the treated sample with respect to the control sample.

\section{Powder X-ray Diffraction (PXRD) analysis}

The PXRD diffractograms of the control and Biofield Energy Treated PLGA samples did not show sharp and intense peaks (Figure 2), indicated that both samples were amorphous in nature. The Biofield Energy Treatment did not affect the crystallinity and pattern of the PLGA.

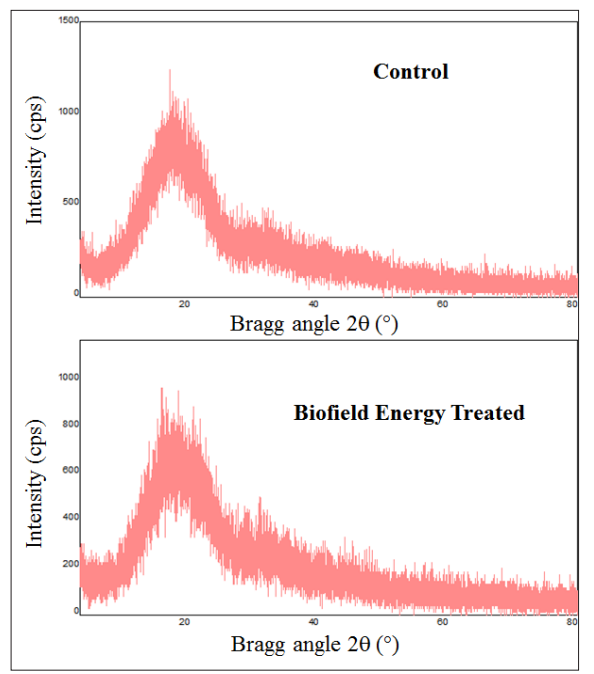

Figure 2: PXRD diffractograms of the control and treated PLGA.

\section{Differential Scanning Calorimetry (DSC) analysis}

The thermal analysis of both the control and Biofield Energy Treated samples showed two endothermic peaks. The control PLGA sampleshowed the sharpendothermic peaksat $61.11^{\circ} \mathrm{C}$ and $329.01^{\circ} \mathrm{C}$ in the thermogram (Figure 3). Similarly, the Biofield Energy Treated PLGA sample showed the sharp endothermic peaks at $61.91^{\circ} \mathrm{C}$ and $325.91^{\circ} \mathrm{C}$ in the thermogram (Figure 3 ). The $1^{\text {st }}$ endothermic peak was due to the evaporation of absorbed water molecule from the sample, whereas the $2^{\text {nd }}$ large endothermic pick was due to the melting of PLGA compounds. The observed thermogram patterns were well matched with the reported data [1]. The evaporation and melting temperature of the Biofield Energy Treated PLGA sample were slightly altered by $1.31 \%$ and $-0.94 \%$, respectively compared to the control sample (Table 2). But, the latent heat of evaporation $\left(\Delta \mathrm{H}_{\text {evaporation }}\right)$ and latent heat of fusion $\left(\Delta \mathrm{H}_{\text {fusion }}\right)$ of the Biofield Energy Treated PLGA sample were significantly increased by $6.91 \%$ and $116.91 \%$, respectively compared with the control sample (Table 2). The evaporation and melting temperature were slightly altered, but the heat energy required by the Biofield Energy Treated sample for the evaporation and melting was significantly increased compared to the control sample. Any change in the molecular chains, and the crystal structure influence the thermal stability [37]. Hence, Dahryn's Biofield Energy Treatment could have disturbed the molecular chains and crystal structure of PLGA, which lead to the increased thermal stability of the treated PLGA sample compared to the control sample.

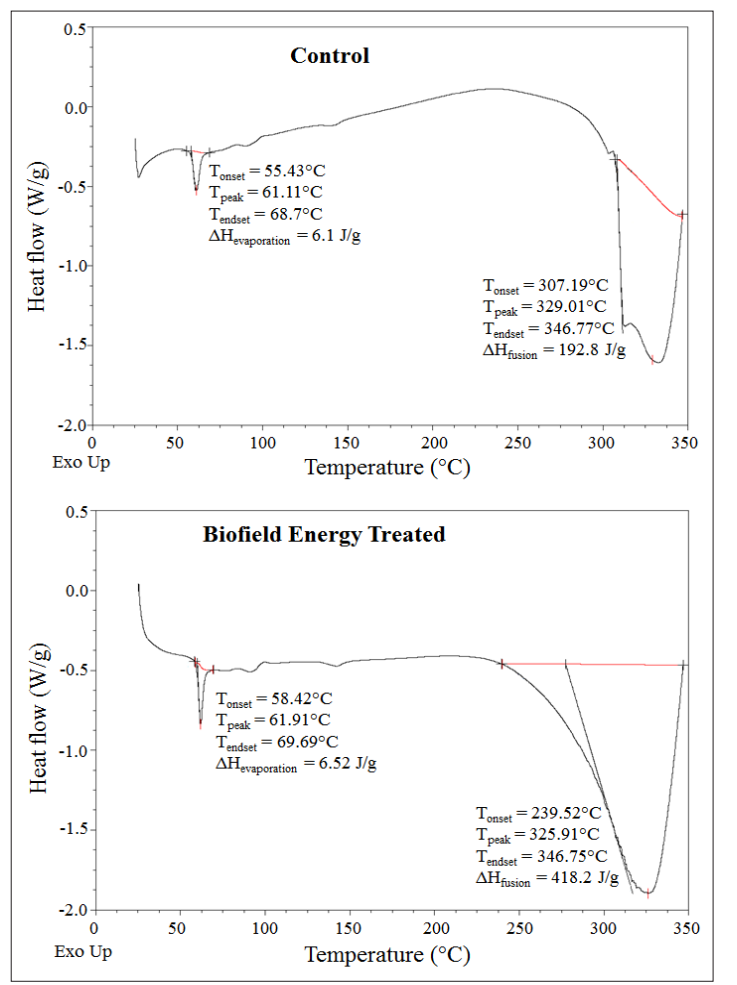

Figure 3: DSC thermograms of the control and treated PLGA. 
Table 2: DSC data for both control and treated PLGA.

\begin{tabular}{|c|c|c|c|c|}
\hline \multirow{2}{*}{ Sample } & \multicolumn{2}{|c|}{ Melting Point $\left({ }^{\circ} \mathbf{C}\right)$} & \multicolumn{2}{|c|}{$\Delta \mathbf{H}(\mathbf{J} / \mathbf{g})$} \\
\cline { 2 - 5 } & $\mathbf{1}^{\text {st }}$ Peak & $2^{\text {nd }}$ Peak & 6.1 & Evaporation \\
\hline Control Sample & 61.11 & 329.01 & 6.52 & 418.2 \\
\hline Biofield Energy Treated & 61.91 & 325.91 & 6.91 & 116.91 \\
\hline \% Change* & 1.31 & -0.94 & & \\
\hline
\end{tabular}

$\Delta \mathrm{H}$ : Latent heat of evaporation/fusion, *denotes the percentage change of the treated PLGA with respect to the control sample.

\section{Thermal Gravimetric Analysis (TGA) / Differential Thermogravimetric Analysis (DTG)}

The TGA/DTG thermograms of the control and Biofield Energy Treated PLGA are displayed in Figure 4 and Figure 5. Both the sample showed one step of the thermal degradation process. The total weight loss in Biofield Energy Treated PLGA (95.07\%) was significantly decreased by $4.1 \%$ compared with the control sample (99.13\%). Therefore, the residue amount was $468.24 \%$ more in the Biofield Energy Treated sample compared to the control sample (Table 3). The thermograms of the control and Biofield Energy Treated PLGA exhibited one sharp peak (Figure 5). The maximum thermal degradation temperature $\left(\mathrm{T}_{\max }\right)$ of the Biofield Energy Treated sample was decreased by $2.37 \%$ compared with the control sample. Overall, TGA/DTG thermal analytical results concluded that the thermal stability of the Biofield Energy Treated sample was increased compared with the control sample.
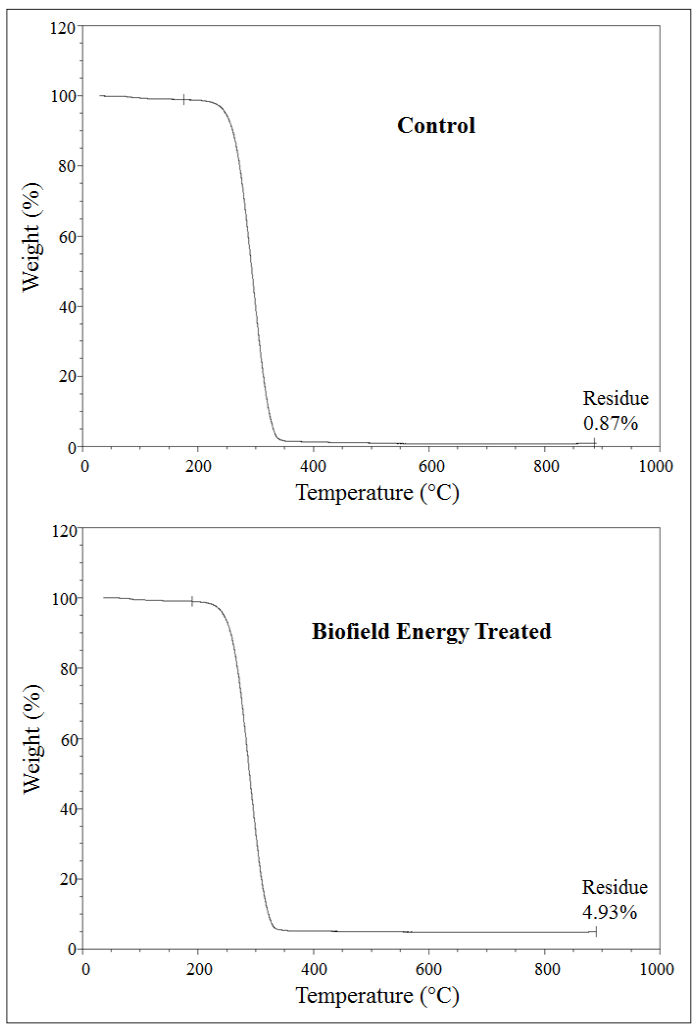

Figure 4: TGA thermograms of the control and treated PLGA.
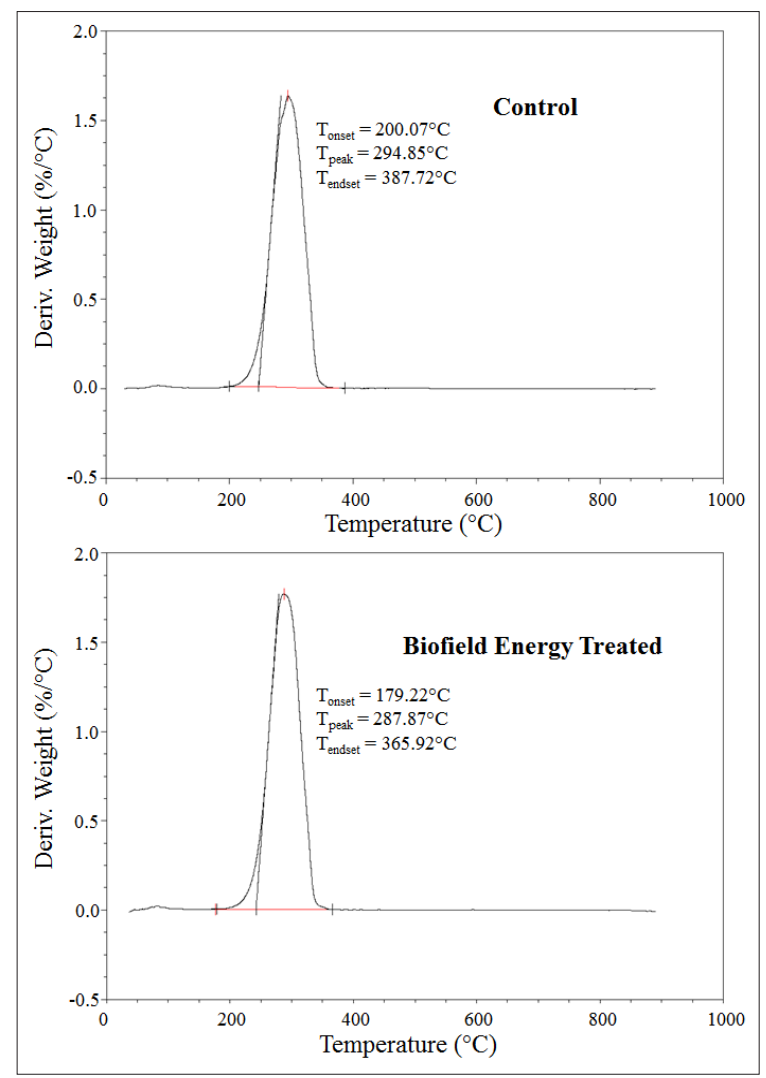

Figure 5: DTG thermograms of the control and treated PLGA.

\section{Conclusion}

The experimental results established that the Trivedi Effect ${ }^{\circledR}$ Consciousness Energy Healing Treatment has a significant impact on the particle size, surface area, and thermal behaviors of the PLGA powder sample. The particle size values of the Biofield Energy Treated PLGA powder were significantly decreased by $48.08 \%, 40.08 \%, 33.78 \%$, and $37.17 \%$ at $d_{10}, d_{50}, d_{90^{\prime}}$ and D $(4,3)$, respectively compared to the control sample. Hence, the specific surface area of the Biofield Energy Treated PLGA powder sample was significantly increased by $72.57 \%$ compared to the control sample. The evaporation and melting temperature of the Biofield Energy Treated sample were slightly altered by $1.31 \%$ and $-0.94 \%$, respectively compared with the control sample. But, the latent heat of $\Delta \mathrm{H}_{\text {evaporation }}$ and $\Delta \mathrm{H}_{\text {fusion }}$ of the Biofield Energy Treated PLGA sample were significantly increased by $6.91 \%$ and $116.91 \%$, respectively 
compared with the control sample. The total weight loss was significantly decreased by $4.1 \%$; however, the residue amount was 21.99\% more in the Biofield Energy Treated PLGA sample compared to the control sample. The $\mathrm{T}_{\max }$ of the treated PLGA was altered by $2.37 \%$ compared with the control sample. From the results, it was established that the Trivedi Effect ${ }^{\circledR}$-Consciousness Energy Healing Treatment might introduce a new form of PLGA, which would show better solubility, dissolution rate, absorption, bioavailability, and thermal stability compared with the control PLGA. This the Trivedi Effect $^{\circledR}$-Consciousness Energy Healing Treated PLGA would be a better choice for the pharmaceutical formulations, i.e., the drug-like amoxicillin, simvastatin, minocycline, and vancomycin loaded PLGA nanoparticles and manufacturing of biomedical devices, i.e., grafts, surgical sealant films, sutures, prosthetic devices, implants, micro, and nanoparticles.

Table 3: TGA/DTG data of the control and treated samples of PLGA.

\begin{tabular}{|c|c|c|c|}
\hline \multirow{2}{*}{ Sample } & \multicolumn{2}{|c|}{ TGA } & DTG \\
\cline { 2 - 4 } & Total weight loss (\%) & Residue \% & T $_{\max }\left(^{\circ} \mathbf{C}\right)$ \\
\hline Control & 99.13 & 0.87 & 294.85 \\
\hline Biofield Energy Treated & 95.07 & 4.93 & 287.87 \\
\hline \% Change* & -4.1 & 468.25 & -2.37 \\
\hline
\end{tabular}

*denotes the percentage change of the treated sample with respect to the control sample,

$\mathrm{T}_{\max }=$ the temperature at which maximum weight loss takes place in TG or peak temperature in DTG.

\section{Acknowledgement}

The authors are grateful to Central Leather Research Institute, SIPRA Lab. Ltd., Trivedi Science, Trivedi Global, Inc., and Trivedi Master Wellness for their assistance and support during this work.

\section{References}

1. Makadia HK, Siegel SJ (2011) Poly lactic-co-Glycolic Acid (PLGA) as biodegradable controlled drug delivery carrier. Polymers (Basel) 3(3): 1377-1397.

2. Erbettan CDC, Alves RJ, Resende JM, Freitas RFS, de Sousa RG (2012) Synthesis and characterization of poly(d,l-lactide-co-glycolide) copolymer. Journal of Biomaterials and Nanobiotechnology 3(2): 208225.

3. Pavot V, Berthet M, Rességuier J, Legaz S, Handké N, et al. (2014) Poly (lactic acid) and poly (lactic-co-glycolic acid) particles as versatile carrier platforms for vaccine delivery. Nanomedicine 9(17): 2703-2718.

4. Shinde AJ, More HN (2011) Design and evaluation of polylactic-coglycolic acid nanoparticles containing simvastatin. Int J Drug Dev \& Res 3(2): 280-289.

5. Dissolvable plastic nanofibers could treat brain infections. Scientific Computing. Advantage Business Media, New Jersey, USA.

6. Kashi TS, Eskandarion S, Esfandyari-Manesh M, Marashi SM, Samadi $\mathrm{N}$, et al. (2012) Improved drug loading and antibacterial activity of minocycline-loaded PLGA nanoparticles prepared by solid/oil/water ion pairing method. Int J Nanomedicine 7: 221-234.

7. Samadi N, Abbadessa A, Di Stefano A, van Nostrum CF, Vermonden T, et al. (2013) The effect of lauryl capping group on protein release and degradation of poly (D,L-lactic-co-glycolic acid) particles. Journal of Controlled Release 172(2): 436-443.

8. Jain RA (2000) The manufacturing techniques of various drug loaded biodegradable poly(lactide-co-glycolide) (PLGA) devices. Biomaterials 21(23): 2475-2490.

9. Gilding DK, Reed AM (1979) Biodegradable polymers for use in surgerypolyglycolic/poly (lactic acid) homo- and copolymers. Polymer 20: $1459-1464$.

10. Anderson JM, Shive SM (1997) Biodegradation and biocompatibility of
PLA and PLGA microspheres. Adv Drug Deliv Rev 28(1): 5-24.

11. Alexis F (2005) Factors affecting the degradation and drug-release mechanism of poly(lactic acid) and poly[(lactic acid)-co-(glycolic acid)]. Polym Int 54(1): 36-46.

12. Hyon SH, Jamshidi K, Ikada Y (1998) Effects of residual monomer on the degradation of DL-lactide polymer. Polym Int 46(3): 196-202.

13. Trivedi MK, Branton A, Trivedi D, Nayak G, Wellborn BD, et al. (2017) Characterization of physical, structural, thermal, and behavioral properties of the consciousness healing treated zinc chloride. World Journal of Applied Chemistry 2(2): 57-66.

14. Trivedi MK, Branton A, Trivedi D, Nayak G, Wellborn BD, et al. (2017) Characterization of physicochemical, thermal, structural, and behavioral properties of magnesium gluconate after treatment with the energy of consciousness. International Journal of Pharmacy and Chemistry 3(1): $1-12$.

15. Trivedi MK, Branton A, Trivedi D, Nayak G, Panda P, et al. (2016) Gas chromatography-mass spectrometric analysis of isotopic abundance of $13 \mathrm{C}, 2 \mathrm{H}$, and 180 in biofield energy treated P-Tertiary Butylphenol (PTBP). American Journal of Chemical Engineering 4(4): 78-86.

16. Trivedi MK, Mohan TRR (2016) Biofield energy signals, energy transmission and neutrinos. American Journal of Modern Physics 5(6): 172-176.

17. Barnes PM, Bloom B, Nahin RL (2008) Complementary and alternative medicine use among adults and children: United States, 2007. Natl Health Stat Report 12: 1-23.

18. Koithan M (2009) Introducing complementary and alternative therapies. J Nurse Pract 5(1): 18-20.

19. Rubik B, Muehsam D, Hammerschlag R, Jain S (2015) Biofield science and healing: history, terminology, and concepts. Glob Adv Health Med 4(Suppl 1): 8-14.

20. Oschman J (2003) Energy medicine in therapeutics and human performance. Philadelphia: Butterworth Heinemann, Oxford, United Kingdom, pp. 1-12.

21. Trivedi MK, Branton A, Trivedi D, Nayak G, Panda P, et al. (2016) Isotopic abundance ratio analysis of 1,2,3-trimethoxybenzene (TMB) after biofield energy treatment (the Trivedi Effect ${ }^{\circledR}$ ) using gas chromatography-mass spectrometry. American Journal of Applied Chemistry 4(4): 132-140. 
22. Trivedi MK, Nayak G, Patil S, Tallapragada RM, Latiyal O, et al. (2015) Impact of biofield treatment on atomic and structural characteristics of barium titanate powder. Ind Eng Manage 4: 166.

23. Trivedi MK, Branton A, Trivedi D, Nayak G, Lee AC, et al. (2017) An investigation of the Trivedi Effect ${ }^{\circledR}$-Energy of Consciousness Healing Treatment to modulate the immunomodulatory effect of herbomineral formulation in male Sprague Dawley rats. Advances in Materials 5(6): 144-153.

24. Trivedi MK, Patil S, Shettigar H, Bairwa K, Jana S (2015) Effect of biofield treatment on spectral properties of paracetamol and piroxicam. Chem Sci J 6: 098.

25. Trivedi MK, Branton A, Trivedi D, Shettigar H, Nayak G, et al. (2015) Antibiogram typing of biofield treated multidrug resistant strains of Staphylococcus species. American Journal of Life Sciences 3(5): 369-374.

26. Trivedi MK, Branton A, Trivedi D, Nayak G, Mondal SC, et al. (2015) Antimicrobial sensitivity, biochemical characteristics and biotyping of Staphylococcus saprophyticus: An impact of biofield energy treatment. J Women's Health Care 4: 271.

27. Trivedi MK, Branton A, Trivedi D, Nayak G, Gangwar M, et al. (2015) Evaluation of vegetative growth parameters in biofield treated bottle gourd (Lagenaria siceraria) and okra (Abelmoschus esculentus). International Journal of Nutrition and Food Sciences 4(6): 688-694.

28. Trivedi MK, Branton A, Trivedi D, Nayak G, Mondal SC, et al. (2015) Evaluation of plant growth regulator, immunity and DNA fingerprinting of Biofield Energy Treated mustard seeds (Brassica juncea). Agriculture, Forestry and Fisheries 4(6): 269-274.

29. Trivedi MK, Patil S, Shettigar H, Gangwar M, Jana S (2015) In vitro evaluation of biofield treatment on cancer biomarkers involved in endometrial and prostate cancer cell lines. J Cancer Sci Ther 7: 253-257.
30. Trivedi MK, Sethi KK, Panda P, Jana S (2017) A comprehensive physicochemical, thermal, and spectroscopic characterization of zinc (II) chloride using X-ray diffraction, particle size distribution, differential scanning calorimetry, thermogravimetric analysis/ differential thermogravimetric analysis, ultraviolet-visible, and fourier transform-infrared spectroscopy. International Journal of Pharmaceutical Investigation 7(1): 33-40.

31. Trivedi MK, Sethi KK, Panda P, Jana S (2017) Physicochemical, thermal and spectroscopic characterization of sodium selenate using XRD, PSD, DSC, TGA/DTG, UV-vis, and FT-IR. Marmara Pharmaceutical Journal 21(2): 311-318.

32. (1997) Desktop X-ray Diffractometer "MiniFlex+". The Rigaku Journal 14: 29-36.

33. Zhang T, Paluch K, Scalabrino G, Frankish N, Healy AM, et al. (2015) Molecular structure studies of (1S,2S)-2-benzyl-2,3-dihydro-2(1Hinden-2-yl)-1H-inden-1-ol. J Mol Struct 1083: 286-299.

34. Langford JI, Wilson AJC (1978) Scherrer after sixty years: A survey and some new results in the determination of crystallite size. J Appl Cryst 11: 102-113.

35. Mosharrof M, Nystrom C (1995) The effect of particle size and shape on the surface specific dissolution rate of microsized practically insoluble drugs. Int J Pharm 122(1-2): 35-47.

36. Buckton G, Beezer AE (1992) The relationship between particle size and solubility. Int J Pharmaceutics 82(3): R7-R10.

37. Zhao Z, Xie M, Li Y, Chen A, Li G, et al. (2015) Formation of curcumin nanoparticles via solution-enhanced dispersion by supercritical $\mathrm{CO}_{2}$. Int J Nanomedicine 10: 3171-3181.

For possible submissions Click below: 